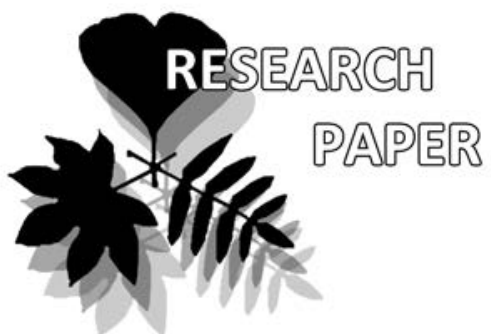

\title{
Dracocephalum charkeviczii Prob. in vitro
}

\author{
Irina V. Gafitskaya ${ }^{1}$, Arkadii B. Bezdelev², \& Olga V. Nakonechnaya ${ }^{1 *}$
}

Irina V. Gafitskaya ${ }^{1}$

e-mail: gafitskaya@biosoil.ru

Arkadii B. Bezdelev²

e-mail: abezd@mail.ru

Olga V. Nakonechnaya ${ }^{1 *}$

e-mail: markelova@biosoil.ru

${ }^{1}$ Federal Scientific Center of the East Asia Terrestrial Biodiversity FEB RAS,

Vladivostok, Russia

${ }^{2}$ Branch of National Scientific Center of Marine Biology FEB RAS, Scientific and Educational centre "Primorsky Aquarium, Vladivostok, Russia

\section{* corresponding author}

Manuscript received: 21.10 .2021 Review completed: 04.01.2022 Accepted for publication: 18.01.2022 Published online: 24.01.2022

\begin{abstract}
A B S T R A C T
We established sterile clones of a medicinal plant dragonhead Dracocephalum charkeviczii Prob. (Lamiaceae). We used shoots of the plants from natural habitat, notably leaf nodes with axillary bud, as explants, sterilized the explants in $0.1 \%$ Diocide for 4 minutes and cultivated them on agarized nutrient half-strength MS medium with vitamins, $2 \%$ sucrose, $0.4 \%$ agar, $1 \mathrm{mg} / 1$ indolylbutyric acid (IBA), or 0.5 or $1.0 \mathrm{mg} / 1$ 6-benzyladenine (BA). Medium pH was 4.6 or 5.4. We took hormonefree half-salt MS medium as a control. We observed the maximum propagation coefficient equal to 9.4 in microplants cultivated on the medium with $1 \mathrm{mg} / 1 \mathrm{BA}$. Application of hormone-free MS medium can be recommended for D. charkeviczii propagation due to its simplicity. The use of the medium protocol with $1 \mathrm{mg} / \mathrm{lBA}$ on the first step and with IBA on the second step will allow rapid multiplication and establishment of full-fledged plants of D. charkeviczii for different purposes such as restoration of natural populations, source of valuable metabolites, landscaping, etc.

Keywords: microcloning, reproduction, rare species, conservation, cultivation conditions, in vitro, Dracocephalum charkeviczii.
\end{abstract}

\section{P E 3 Ю M E}

Гафицкая И.В., Безделев А.Б., Наконечная О.В. Змееголовник Харкевича (Dracocephalum charkeviczii Prob.) in vitro. Получены стерильные клоны редкого мекарственного растения змееголовника Харкевича (Dracocephalum charkeviczii Prob. (Lamiaceae)). В качестве эксплантов брали черенки растений из природных местообитаний (листовой узел с пазушной почкой), стерилизовали $0.1 \%$ раствором диацида в течение 4 мин и выращивали на твердой питательной среде с минеральной основой по Мурасиге и Скугу, содержавшей витамины, сахарозу $2 \%$, агар-агар $0.4 \%, 1$ мг/ инАОлиммас яной кислоты (ИМК), БАП - 0.5 мг/А или 1 мг/ . $\mathrm{pH}$ среды 4.6 или 5.4. А^я контроля использовали безгормональную среду, содержащую половинную концентрацию микро- и макросолей. Максимальный коэффициент размножения отмечен у растений, культивированных на среде с Аобавлением 1 мг / БАП, составим 9.4. Использование безгормональной среды (контроль) может быть рекомендовано Аля размножения D. charkeviczii из-за одноэтапности и наименьшей ресурсозатратности. Применение протокола с добавлением 1 мг / БАП на первом этапе культивирования и ИМК на втором этапе позволит быстро размножить до необходимого количества и получить полноценные растения D. charkeviczii Аля восстановления природных популяций, как источник ценных БАВ, Аля озеленения.

КАючевые слова: микроклонирование, размножение, редкий виА, сохранение, усмовия культивирования, Dracocephalum charkeviczii, in vitro
Dracocephalum charkeviczii Prob. is a herbaceous perennial plant (Fig. 1a, b) from the large Lamiaceae family, close to D. argunense Fisch. ex Link. It is a circum-Japan sea coastal meadow and psammo-petrophilic species that inhabits seaside meadows, slopes of sea terraces, seaside sands and pebbles on the islands of the Peter the Great Bay near Vladivostok; in Ussuriysk, Partizansk, Khasan, Ternei districts of Primorye Territory; in Sikhote-Alin Reserve; in YuzhnoKurilsk (Kunashir island), Sakhalin Region. Outside Russia, it is found in coastal areas of Japan and China (Probatova \& Krestovskaya 1995, Seledets 2007, Probatova et al. 2016). The range of the species is elongated and fragmented due to certain habitat condition demands. Biotopes of this species undergo considerable anthropogenic influence as the sea coasts are increasingly used by population for recreation.
Habitat destruction or degradation in result of active exploitation by humans lead to a significant population decline and put its existence at risk.

D. charkeviczii is a medicinal plant. Leaves of this plant contain rosmarinic acid and rabdosiin (Nakonechnaya et al. 2022 , in press). Rosmarinic acid displays antiviral and antiinflammatory properties (Swarup et al. 2007), and is used as an anticancer agent (Anusuya \& Manoharan 2011). Rabdosiin possess antiallergic, antioxidant, neuroprotective and anti-HIV activity (Trifan et al. 2020).

The plants of D. charkeviczii are attractive and used for decoration of alpine slides and rocky gardens. The use of natural populations of $D$. charkeviczii for medical application is impossible due to its rarity. Therefore, it is necessary to find a method for rapid and reliable plant propagation without 
damage to natural populations for practical application of $D$. charkeviczii. Method of micropropagation is a good alternative. The aim of this work was to develop approaches for D. charkeviczii micropagation, which is important as the first step to save and restore the natural populations.

\section{MATERIAL AND METHODS}

The studies were conducted at the Federal Scientific Center of the East Asia Terrestrial Biodiversity, Far Eastern Branch of the Russian Academy of Sciences (FSCEATB FEB RAS, Vladivostok), in the sector of microclonal propagation of forest, agricultural and ornamental plants in 2018 .

Dracocephalum charkeviczii, a perennial summer-green herbaceous sympodially growing polycarpic plant with short rhizome and elongated mocarpic ascending stem (Bezdelev \& Bezdeleva 2006, Voronkova et al. 2008), was the object of the study. The plant grows up to $55 \mathrm{~cm}$ tall, with erect or ascending foliose stems with active axillary branching, linear-lanceolate leaves up to $7 \mathrm{~cm}$ long and 5 (8) $\mathrm{cm}$ wide, overall round-oval inflorescence up to 5 (9) $\mathrm{cm}$ long, blue-violet flowers up to $7 \mathrm{~cm}$ long, and rounded triangular, unclearly ribbed on the back, dark-brown seeds about 3 mm long (Probatova \& Krestovskaya 1995).

Plants of $D$. charkeviczii were collected in natural populations on the gently sloping areas of the coastal gravellystony cliffs covered with vegetation usual for the coastal meadows on the Zhitkov Peninsula (Russian Island, Primorye Territory).

Stem samples with one leaf node and two axillary buds were used as explants. Diocide (0.1\% solution) for 2-4 min was used for explant sterilization (Butenko 1964).

Two ways were used to obtain microplants: one-step way with auxin application (microplants cutting) and two-steps way with cytokinin application (formation of a large quantity of microshoots followed with their rooting). Five different solid nutrient media were used to grow microplants.

Medium 1 - Murashige and Scoog MS (Murashige \& Scoog 1962) half-strength hormone free medium supplemented with vitamins by Butenko (1964), $2 \%$ sucrose and $0.4 \%$ agar.

Medium 2 - the same medium, supplemented with $1 \mathrm{mg} / \mathrm{l}$ IBA (indolylbutyric acid) at $\mathrm{pH}$ 4.6.

Medium 3 - the same medium with $1 \mathrm{mg} / \mathrm{l} \mathrm{IBA}$ and pH 5.4.

Medium 4 - MS with $0.5 \mathrm{mg} / 1$ 6-benzyladenine (BA) and pH 5.0.

Medium 5 - the same medium with $1 \mathrm{mg} / \mathrm{lBA}$ and $\mathrm{pH}$ 5.0.
On the second step we transferred the established multiple microshoots from the medium with cytokinin IBA to the medium 2 with $1 \mathrm{mg} / \mathrm{l} \mathrm{IBA}$ and $\mathrm{pH}$ 5.0. Medium 1 was used as a control.

The media were autoclaved for 20 minutes at 0.8 atmospheres. Plantlets were cultivated at $24 \pm 1^{\circ} \mathrm{C}$, with $70 \%$ air humidity and 16 hours photoperiod under fluorescent lamps with an illumination intensity of 4000 lux. In vitro cultivation was carried out for 8 weeks. After that plantlets were transferred into soil "BIUD Flower "PALISAD" Garden without chemistry (pH 5.6-6.7)" from LLC "Eco-AgTi".

Morphometric measurement of plantlets (plant height, root number and length) was carried out weekly during the cultivation period. The data were analyzed using "Statistica" package version 10.0 and MS Excel 2010. Results were represented as mean with standard error of mean.

\section{RESULTS AND DISCUSSION}

Introduction in vitro. Sterilization of explants with $0.1 \%$ Diocide for 4 minutes allowed us to establish $92 \%$ of sterile explants capable to regenerate. This method appeared to be optimal for successful introduction of D. charkeviczii into culture.

We observed callus formation on the explant end dipped into medium (Fig. 1c). Callus cells then formed roots. Proliferation of the bud shoots and root development took place 3-4 days after planting. Microshoots contained 2-4 leaf nodes. We used microplants established after 4 weeks of culturing for further microclonal propagation.

Microclonal propagation. We noticed the beginning of axillary shoots proliferation and root rudiments laying after 3-4 days of culturing on media 1-3. The highest rates of axillary buds induction and microshoots development were observed in control (MS half-strength hormone-free medium). Plantlets on this medium reached $3 \mathrm{~cm}$ high after four weeks of culturing (Table 1). Microshoot and root formation took place identically with what was previously shown during introduction into culture. Only $29.17 \%$ of explants formed roots. The root length reached $6.5 \mathrm{~cm}$ with the maximum of 2 roots on the explant. Propagation coefficient was equal to 3 (Table 1 ).

Nutrient media supplemented with IBA provided the slowdown of bud induction in explants, comparing with control hormone-free medium. Growth of microplants on medium 2 (IBA, pH 4.6) was equal to growth of control microplants, whereas root formation was more intensive (Table 1). After two weeks of culturing almost half of the microshoots $(44.74 \%)$ had roots of different length. Some microshoots $(18.42 \%)$ had two and more roots (Fig. 1d).

Table 1. Morphometric characteristics of Dracocephalum charkeviczii

\begin{tabular}{lcccc}
\hline Microplant parameters & $\begin{array}{c}\text { Medium 1 } \\
\text { (control) }\end{array}$ & $\begin{array}{c}\text { Medium 2 } \\
\text { (IBA pH 4.6) }\end{array}$ & $\begin{array}{c}\text { Medium 3 } \\
\text { (IBA pH 5.4) }\end{array}$ & $\begin{array}{c}\text { Medium 4 } \\
\text { (0.5 mg/1 BA) }\end{array}$ \\
\hline Microplant hight, mm & $29.56 \pm 2.51$ & $28.83 \pm 2.08$ & $26.04 \pm 2.26$ & $\begin{array}{c}\text { Medium 5 } \\
\text { (1 mg/1 BA) }\end{array}$ \\
The number of roots & $0.45 \pm 0.16$ & $1.08 \pm 0.18$ & $0.27 \pm 0.19$ & $30-120$ \\
Length the first root, mm & $6.46 \pm 2.41$ & $15.98 \pm 3.26$ & $5.78 \pm 3.93$ & - \\
Length the second root, mm & $3.04 \pm 1.70$ & $8.36 \pm 2.44$ & $2.21 \pm 2.21$ & - \\
Length the third root, mm & $0 \pm 0$ & $3.68 \pm 1.72$ & $0 \pm 0$ & - \\
Portion of rooted microshoots, \% & 29.17 & 52.63 & 22.22 & - \\
Propagation coefficient & 3 & 2.90 & 2.61 & - \\
\end{tabular}




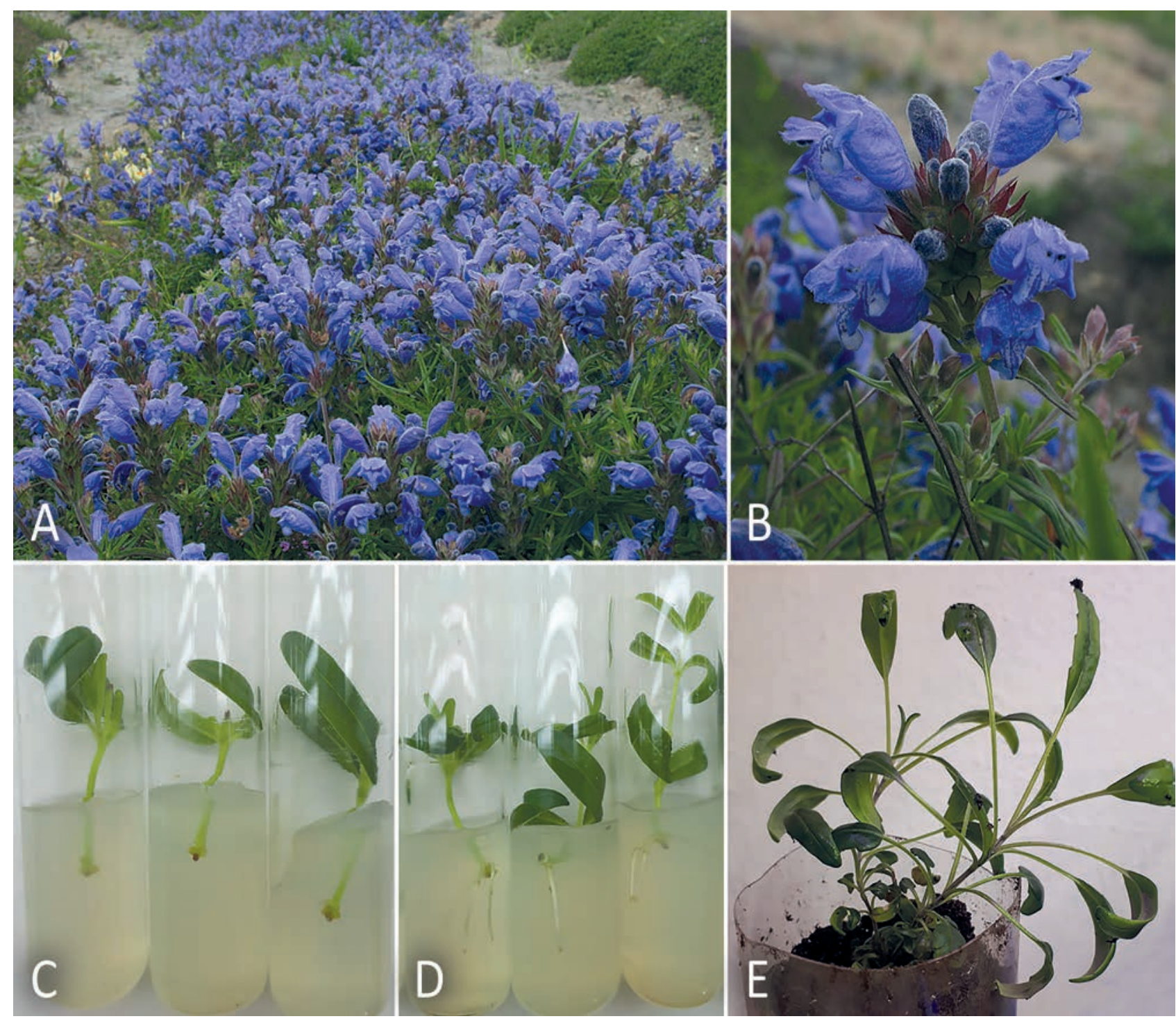

Figure 1 Dracocephalum charkeviczii. Prob. A - plants in population; B - inflorescence; C and D - explants after 1 and 2 weeks of cultivation, respectively; D - plant in the soil

After three weeks of cultivation root length increased 3 times, comparing with previous measurement. We noted positive growth dynamics for $7.89 \%$ more explants. Thus, $52 \%$ of explants have rooted by this time (Table 1). After 4 weeks of cultivation the growth processes slowed down, the microshoot height and root length increased insignificantly, what may be due to a medium degradation.

Microshoots on the medium 3 (IBA, pH 5.4) grew slower than microshoots in control group and on medium 2. We noticed rooting in $20 \%$ of explants. The root length was the smallest among all experimental groups (Table 1). Propagation coefficient was lower than that for control microshoots.

On the media supplemented with BA 0.5 and $1.0 \mathrm{mg} / 1$ (media 4 and 5) multiple shoots started to develop 5-7 days after planting. Microshoots grew higher than those in other experimental groups (Table 1). Addition of BA to the media caused the formation of watered (aqueous) microshoots. On the medium 4 with less BA content $32 \%$ of microshoots were watered, and $14 \%$ of microshoots were watered on the medium with $1 \mathrm{mg} / 1 \mathrm{BA}$. Propagation coefficient for explants on media 4-5 was higher, comparing with the other media (Table 1). We observed maximal propagation coefficient on medium 5 with $1 \mathrm{mg} / \mathrm{l} \mathrm{BA}$. It should be noted that the greater the number of nodes on microshoots, the more material for micropropagation will be obtained.

On the second stage of the experiment, we took multiple microshoots established on media 4 and 5, and placed them on the medium 3 in order to stimulate rooting. During 6 weeks of culturing plantlets on this media grew higher $(53.83 \pm 1.34 \mathrm{~mm})$ than plantlets on other media in the first experiment. Root number was equal to $30.8 \pm 3.1$; the first root length was equal to $101.2 \pm 11.0 \mathrm{~mm}$, the second root length was equal to $70.7 \pm 9.7 \mathrm{~mm}$, the third root length was equal to $44.4 \pm 5.2 \mathrm{~mm}$.

Based on the results of the experiment with five medium variants we can conclude that different protocols can be applied for different purposes: scientific (preservation and restoration of natural populations) and industrial (multiplication and build-up of material for production of valuable biologically active compounds). Application of hormone- 
free medium (control) allowed us to obtain full-fledged microplants, and can be recommended for further propagation, as it is a one-step and less resource-intensive way. At the same time, the use of medium $5(1 \mathrm{mg} / \mathrm{l} \mathrm{BA})$ on the first culturing step and medium 2-3 (with IBA) on the second step will enable fast establishment of a large quantity of microplants that can be used for any purposes.

Micropropagation method was previously applied for propagation of other rare medicinal plants of the genus Dracocephalum - D. kotschyi Boiss. (Otroshy \& Moradi 2011, Zeinali et al. 2014), and D. ruyschiana (Klavina et al. 2004). The authors used hormone-free MS medium (Klavina et al. 2004), or supplemented it with BA or kinetin in three concentrations $(0,1.0,2.0 \mathrm{mg} / \mathrm{l})$, together with indoleacetic acid (IAA) or $\alpha$-naphthaleneacetic acid (NAA) (Otroshy \& Moradi 2011).

Medium 2 (IBA, pH 4.6) provided the highest quantity of the rooted microplants, which was two times higher than that on medium 1 (control) and medium 3 (IBA, pH 5.4). Previously, Zeinali et al. (2014) showed the same best rooting percentage equal to $30 \%$ for another species D. kotschyu on MS medium supplemented with $0.2 \mathrm{mg} / 1$ IBA or $0.5 \mathrm{mg} / 1 \mathrm{IBA}$ and $1 \mathrm{mg} / 1$ kinetin. Otroshy \& Moradi (2011) reported on a $90.08 \%$ of rooted explants using the medium supplemented with $2 \mathrm{mg} / 1 \mathrm{BA}$ and $0.5 \mathrm{mg} / 1 \mathrm{NAA}$.

The propagation coefficient for $D$. charkeviczii appeared to be lower (3) (Table 1) than that reported for D. ruyschiana on hormone-free MS medium - 4.2 (Klavina et al. 2004). The difference can be explained by a cultivation period or features of the studied species.

Adaptation of plantlets to soil. The use of the soil mixture and closed cultural vessels ensured the survival of $72.5 \pm 7.5 \%$ plants. During two months of cultivation the plantlets grew in size (Fig. 1e), developed abundant root system and were ready to a transfer to an open soil. Zeinali et al. (2014) showed that plants of D. kotschyi displayed $100 \%$ survival rate and active growth after planting into a mixture of peat, coconut flakes, and perlite (2:1:1). This index was lower for D. ruyschiana reaching only $28 \%$ (Klavina et al. 2004).

\section{CONCLUSION}

Thus, an effective method of introduction of $D$. charkeviczii into culture was developed. Our results showed that control hormone-free MS medium was optimal for D. charkeviczii plantlets cultivation, as it was less resourceintensive. However, application of distinct plant growth regulators such as $1 \mathrm{mg} / \mathrm{l} \mathrm{BA}$ on the first cultivation stage and IBA on the second cultivation stage would allow rapid production of a large quantity of full-fledged microplants ready for use for different purposes.

\section{LITERATURE CITED}

Anusuya, C. \& S. Manoharan 2011. Antitumor initiating potential of rosmarinicacid in 7,12-dimethylbenz(a)anthracene-induced hamster buccal pouch car-cinogenesis. Journal of Environmental Pathology 30(3):199-211.

Bezdelev, A.B., T.A. Bezdeleva 2006. Life forms of seed plants of the Russian Far East. Dalnauka, Vladivostok, 296 pp. [Безделев А.Б., Безделева Т.А. 2006. Жизненные формы семенных растений российского Аальнего Востока. ВАадивосток: Аальнаука. 296 с.].

Butenko, R.G. 1964. Culture of isolated tissues and physiology of plant morphogenesis. Nauka, M., 272 pp. ББутенко Р.Г. 1964. Культура изолированных тканей и физиология морфогенеза растений. М.: Наука. 272 с.].

Kḷaviņa, D., A. Gailīte, G. Jakobsone, J. N̦ečajeva \& İ. Gavrilova 2004. Tissue culture technology in conservation of threatened plant species of Latvia. Latvijas Universitates Raksti 676:183-188.

Murashige, T. \& F. Skoog 1962. A revised medium for rapid growth and bio-assays with tobacco tissue cultures. Physiologia Plantarum 15(3):473-497.

Nakonechnaya, O.V., I.V. Gafitskaya, V.P. Grigorchuk, T.Yu. Gorpenchenko, A.B. Bezdelev \& Yu.N. Zhuravlev 2022. Composition of plant polyphenols of Dracocephalum charkeviczii Prob. in situ and in vitro. Russian Journal of Plant Physiology 69(2): in press. [Наконечная O.B., Гафицкая И.В., Григорчук В.П., Горпенченко Т.Ю., Безделев А.Б., Журавлев Ю.Н. 2022. Состав полифенолов растений Dracocephalum charkeviczii Prob. в условиях in situ и in vitro // Физиология растений. T. 69(2):171-178].

Otroshy, M. \& K. Moradi 2011. Micropropagation of medicinal plant Dracocephalum kotschyi Boiss. via nodal cutting technique. Journal of Medicinal Plants Research 5(25):5967-5972.

Probatova, N.S., V.Yu. Barkalov \& V.A. Nechaev 2016. Further chromosome studies on vascular plants in Primorsky Krai. Uchenye Zapiski Zabaikal'skogo Gosudarstvennogo Universiteta. Seriya Estesnvennye Nauki 11(1):27-37 [Пробатова Н.С., Баркалов В.Ю., Нечаев В.А. 2016. Хромосомные чис $а$ сосудистых растений в Приморском крае: Аальнейшее изучение // Ученые записки Забайкальского государственного университета. Серия: Естественные науки. Т. 11(1). С. 27-37].

Probatova, N.S. \& T.V. Krestovskaya 1995. Family Lamiaceae. In: Vascular Plants of the Soviet Far East, vol. 7 (S.S. Kharkevich, ed.), pp. 294-380, Nauka, Saint Petersburg. [Проб̆атова Н.С., Крестовская Т.В. 1995. Яснотковые - Lamiaceae / / Сосудистые растения советского Аальнего Востока / отв. реА. С.С. Харкевич. СПб: Наука. Т. 7. С. 294-380].

Seledets, V.P. 2007. On the flora of nature monuments in the Primorskii Krai. Bulletin of the Botanical Garden Institute FEB RAS 1(1):96-102 [Селелец В.П. 2007. К флоре памятников природы Приморского края // Бюмлетень Ботанического сада института $\triangle \mathrm{BO}$ РАН. Вып. 1(1). C. 96-102].

Swarup, V., J. Ghosh, S. Ghosh, A. Saxena \& A. Basu 2007. Antiviral and anti-inflammatory effects of rosmarinic acid in an experimental murine model of Japanese encephalitis. Antimicrobial agents and chemotherapy 51:3367-3370.

Trifan, A., E. Wolfram, N. Esslinger, A. Grubelnik, K. Skalicka-Woźniak, M. Minceva \& S.V Luca. 2020. Globoidnan A, rabdosiin and globoidnan B as new phenolic markers in European - sourced comfrey (Symphytum officinale L.) root samples. Phytochemical Analysis 32(4):482-494.

Voronkova, N.M., E.V. Burkovskaya, T.A. Bezdeleva \& O.L. Burundukova 2008. Morphological and biological features of plants related to their adaption to coastal habitats. Russian Journal of Ecology 39(1):1-7.

Zeinali, S., M. Otroshy, A. Sadrarham, K. Moradi \& A. Mokhtari 2014. Influence of plant growth regulators on in vitro culture and regeneration of Dracocephalum kotschyi. International Journal of Agriculture Innovations and Research 3(1):108-111. 